\title{
Effects of COVID-19 in E-learning on higher education institution students: the group comparison between male and female
}

\author{
Arfan Shahzad ${ }^{1} \cdot$ Rohail Hassan $^{1}$ (D) $\cdot$ Adejare Yusuff Aremu ${ }^{1} \cdot$ Arsalan Hussain $^{1}$. \\ Rab Nawaz Lodhi
}

Published online: 4 August 2020

(c) Springer Nature B.V. 2020

\begin{abstract}
In response to the emerging and ever solution to the COVID-19 outbreak. This study proposes a theoretical framework based on literature and model to determined E-learning portal success. The study compared males and females to E-learning portal usage. The study objective is to check the difference between male and female E-learning portals' accessibility among the students' perspective. The study included service quality, system quality, information quality, user satisfaction, system use, and E-learning portal success. The empirical data of 280 students participated from the different universities of Malaysia through google surveys analyzed using the Partial Least Squares Structural Equation Modelling. The study further divided the full model into two domains, which are female and male. In the male model, information quality and system quality have direct relationships with user satisfaction. Information quality also supported the relationship with system use. At the same time, there is a positive relationship between user satisfaction and E-learning portals. Likewise, in the female model, E-service quality and Information quality both are supported by system use and user satisfaction. Similarly, system quality has a positive relationship with user satisfaction, and user satisfaction has a positive relationship with E-learning portals. The study will be further helpful for the Malaysian universities policy-makers such as top management, ministry of higher education, Malaysian universities union in designing the policies and programs on E-learning Portal Success in the country. The findings of the study reveal that males and females have a different level of in terms of usage of towards E-learning portals in Malaysian Universities.
\end{abstract}

Keywords E-learning portal $\cdot$ System quality $\cdot$ Information quality $\cdot$ Higher education institution - Gender

Rohail Hassan

rohail.hassan@uum.edu.my

Extended author information available on the last page of the article 


\section{Introduction}

In the 21st century, at the end of 2019 in Wuhan, the high technology business hubs of China experience an epidemic of an entirely distinctive coronavirus appeared that had killed a few thousand Chinese within the fifty days of spreads and thousands of other citizens are suffered. The novel virus was nominated as COVID-19 novel coronavirus by the Chinese scientists (Shereen et al. 2020). Later on, in a shorter period, this COVID-2019 spread worldwide. Several country's economies are severely affected due to COVID2019. Further, the outbreak has changed the operating conditions all over the globe within a month. The consequences of a pandemic are unstoppable and uncontrollable for many industries of the world. Later on, almost 120 countries have stopped face-to-face learning; approximately a billion students' education is effected worldwide with COVID-19. Most of the higher education system is operating through the E-learning (Azzi-Huck and Shmis 2020; Shahzad et al. 2020a, b). Meanwhile, to tackle the COVID-19 pandemic, almost all the world, and including Malaysian higher education ministry, has issued the ordered to close the public school and higher education closure as an emergency measure to stop spreading the infection.

Technologies have changed the traditional way of education to the modern way of learning, like artificial intelligence (Di Vaio et al. 2020a). Thus E-learning is covered under a larger term of technology-based learning through websites, learning portals, video conferencing, YouTube, mobile apps, and thousand types of free available websites for blended learning tools. Currently, E-learning is enhancing students' knowledge, even the academic staff and professional and industry people skills through the internet (Adams et al. 2018; Chopra et al. 2019). Most of the higher education universities are providing online courses for their students within and off campuses. In Malaysia, the Government is providing many resources to higher education. Based on the news reports, the Malaysian universities, colleges, polytechnics are using Massive Open Online Courses (MOOCs). The growth of the online education market is expected $16.4 \%$ annually over the forecast period, 2016-2023. With the massive growth of the internet, maybe university teaching and learning models will be changed in 10 to 15 years. Thus, it based on male and female students on the use of the E-learning portal. This study focuses on comparisons between male and female counterparts on E-learning portal usage among university students during the COVID-2019 period.

Globally, due to COVID-19 outbreak universities closed and lockdown, most teachers and students are happy by the move online education. The faculty members of worldrenowned universities have begun to get online instructor certifications to deliver online teaching to their students. At the same time, faculty and staff members are learning how to use online learning platforms. Previous, they are using only the delivery through face-toface teaching. However, the shift to online mode has raised many queries on the quality of education (Sahu 2020).

Furthermore, the quality of education and excellent infrastructures such as computers and IT modern equipment reception are now in massive demand and universities are changing their teaching models with the use of intellectual capital (Alvino et al. 2020; Di Vaio et al. 2020b). Thus, an unexpected shift from face-to-face learning to online, there are few difficulties faced by students and lectures. Moreover, most of the countries significant issues with technological infrastructure in rural areas; thus, the standard of online education may be a critical issue that needs essential focus. Therefore, based on the above-said 
issues, this study tries to investigate the impact of male and female students on the use of the E-learning portal.

In previous literature, the D\&M model is tested on the overall population, like banks and other financial sectors. In the current study, the whole population is divided into males and female categories to hoped different theoretical contributions by having a division of the population. Consequently, universities in Malaysia are offering an online course to the students on campus and off-campus. The current study focuses on the male and female user satisfaction and E-learning system use toward the E-learning portal success of the Malaysian universities. Based on many researchers (Cidral et al. 2018; Selvaraj 2019) claimed that user satisfaction and E-learning system use have a significant impact on success. This study will conduct on the students how are enrolled with Malaysian universities and using the E-learning Portal for their learning. Based on the argument so far, there is a still gap in literature the E-learning system among universities after the spread of the Covid-19 outbreak on higher education closure. The purpose of the present study to investigate the effect of information quality, system quality, and service quality toward user satisfaction and E-learning system use impact on the E-learning portal success. Therefore, the study focuses on group comparison between male and female students on the E-learning portal uses.

This paper contains five major sections. Section 2 briefly described the compiling review of previous literature that how the learning curve has shifted towards online portals by using DeLone and McLean Model. In Sect. 3, a description of the research method and the overall process of data collection and analysis were the main focus. Section 4 relates to the Multi-Group Analysis (MGA) and the interpretation of the result. Lastly, Sect. 5 concluded with a holistic discussion related to the male and female groups of the study.

\section{Literature review}

\subsection{Learning shifting toward online}

Toward the end of February, as alerts sounded on the increasing spread of the COVID19 infection, the World Bank built up a multi-sectoral worldwide task force team to help nation reaction and adapting measures. At that point, just China and some other influenced nations were upholding social distance through the closure of schools. In the meantime, following fourteen days after the fact, 120 countries have closed schools impacting almost a billion students across the world that have experience closures of their schools for the period (Azzi-Huck and Shmis 2020). In this light, the COVID-19 pandemic has forced the universities to close face-to-face education and send students home. This force the universities to introduce courses through online portals. Also, education industries are adopting the technologies available such as digital Video conferencing platforms like Zoom, Microsoft platform, and Webex Blackboard and Google Classroom (Larry 2020). Therefore, this will be enhancing E-learning globally (Chen 2010; Yengin et al. 2011; Larry 2020).

Therefore, the current study concentrating on the comparison between male and female on E-learning. In this light, applying remote learning and education resources to mitigate the loss of learning: In web-based technology, Electron Learning is well-knowns as well as the earliest application (Azhari and Ming 2015). In today the E-learning is getting very popular worldwide. E-learning is described as the delivery of learning through technology and the internet (Gros et al. 2016; Hong et al. 2017; Aljawarneh 2020). Almost all 
the universities and colleges have developed the E-learning portal of their students and faculties (Moore et al. 2011). In the 21st century, the E-learning creates a more significant impact on all types of the student, much as the part-time and Full-time or distance learning student in the higher education institution (Azhari and Ming 2015). Nowadays, the majority of the postgraduate students are registered as a part-time student, because they are working in the companies. E-learning helps them a lot because of their time constrain. The advancement in E-learning has been started through Massive Open Online Courses (MOOCs) for students, society, and the industry as well since 2012 (Calisir et al. 2014; Margaryan et al. 2015). MOOCs are recognized as a significant development in higher education million of the peoples and student are taking the benefits and uplifting the existing skill (Gupta and Gupta 2020). Moreover, in recent decades, several Malaysian Universities have adopted the E-learning portals (Hussin et al. 2009; Paechter and Maier 2010). Based on the research of Azhari and Ming (2015) highlighted several issues related to the Learning Management System (LMS) of the Malaysian universities such as the lack of trained lectures, slow down of the internet speed, WIFI coverage, infrastructure, the interface of design, quality of content, system use and students' adoption. In the present research, the comparison between male and female students is measured based on E-learning portal success. Meanwhile, the researchers will find out the importance of E-learning tools' success in terms of male and female Malaysian student perspectives.

\subsection{Model of DeLone and McLean model (D\&M)}

D \& M model ISS success model has gained significant attention from researchers in the field of information systems. In 1992, this model was initially developed by DeLone and McLean to measure the dependent construct of IS success (DeLone and McLean 1992) was primarily based on following three aspects: (Shannon and Weaver 1949) study on communications, Taxonomy of (Mason 1978) measuring information output and Research work on information system during that period. There are three levels of communication per (Shannon and Weaver 1949) First Level: Technical: (accuracy of information system) Second level: Semantic (success of right information conveyed to the right receiver) Third level: Effectiveness (influence of information on the receiver). The information success model (1992) has discussed the six dimensions, such as information quality, system quality, system use, user satisfaction, and organizational impact. After one decade, the author modified the original model by adding service quality dimension and the end replaced the individual impact and organizational impact with the net benefits. Figure 1 showed the original D\&M Model having Six interdependent dimensions (DeLone and McLean 1992; Mohammadi 2015). In this model, the "system Quality" construct depicts "technical success." In contrast, the "Information quality" variable demonstrate "semantic success,"

Fig. 1 Updated DeLone and McLean IS Success Model (D\&MISSM) Source: Delone and McLean (2003)

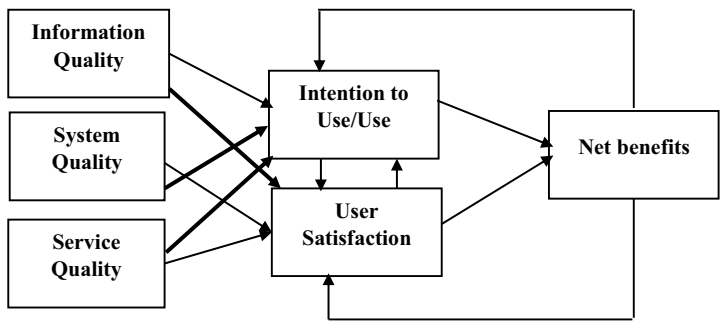


while the other four elements "use," "user satisfaction," "individual impact," and "organizational impact" show "effectiveness success." Therefore, this study focus on male students' comparison with female students on the E-learning portal.

As time passed, the researcher used D\&M Model to check the success of the information communication system. Many studies suggested to add the new dimensions of D\&M model, and some have recommended to include the such as "service quality," "workgroup impact," "consultant/vendor quality" in the D \& M model (Gable et al. 2003; Ifinedo 2006). While the few researchers criticize D \& M Model "use" and "user satisfaction," dimensions. Many studies have changed the number of aspects according to their context, but no study considers organization capabilities mediating role in the relation between alone impact and organizational impact. In this light, a comparison of males and females among university students to determine the E-learning portal.

The study of Ifinedo (2011) highlights the importance of the system quality creates a great impact on the E-learning portal. The system quality of the E-learning will generate query results more quickly. Moreover, system quality will increase the interest of the enduser. Also, the user-friendly interface and modern graphical interface increase the level of user satisfaction. The study of Petter et al. (2013) highlighted that service provider should adopt the new changes and modify time to time the system. Also, the system quality construct has been used in the context of the E-learning system, which depicts whether the user is satisfied with the quality of the E-learning portal. "Perceived ease of use" is the most used measure of "system quality" (Davis, 1989).

Furthermore, SQ has been identified as ease of learning, ease of use, the convenience of access, the usefulness of system features, system complexity, system features, and response time of information system (Beheshti and Beheshti 2010). Furthermore, as suggested by Sedera et al. (2013), SQ means ease of learning, efficient, consistent, modifiable, efficient, personalizable, meets the requirements, ease of use, and reliable. In addition, (DeLone and McLean 2016) acknowledged system quality by measures: ease of use, availability, flexibility, reliability, usefulness, and response time. There are certain modifications in standards of system quality that occurs over time. However, some measures remain the same and consistently being applied and validated, which are as follows: the luxury of use, the comfort of learning, reliability, personalizabality, reply-time, availability, system Interactivity, and system security. Moreover, the study concentrates on the male and female comparison.

The IQ depicts the precision as well as the accuracy of the information provided by the E-learning system; timeliness is another important indicator of information quality that information should be generated within time and latest. So, that higher management can make quick decisions, sufficiency is another characteristic of information quality that it should not be insufficient and must contain all information required to the user. Understandability is a very effective characteristic of the IQ construct that it should be easy to understand and should not be complex that difficult to grasp. Conciseness is another vital part of information quality produced by the E-learning system, system in any organization (Petter et al. 2013; Cai and Zhu 2015; Chiang et al. 2019). Additionally, Information quality demonstrates the output characteristics of the information system that it is proving the timely information to all the departments of the organization; the information should be relevant to the particular user or the department. The required information is available at the right time to the right person; the data' provided by the information system should be understandable to the users (Ifinedo, 2014; Muda and Erlina 2019; Pham et al. CR55). Therefore, the comparison of male and female students on the E-learning portal is the target of this study. 
Furthermore, the main purpose of information quality is to provide users online knowledge with correct relevant information on $24 / 7$. So, it must be considered active for the E-learning portal success. Information quality in past literature considered being part of user satisfaction measurement. It is not treated as a separate variable further argued that information quality measures vary depending upon the type of information system success going to be evaluated. However, there are consistent measures of information quality for E-learning success as follows: Relevance, Usefulness, Understandability, Accuracy, Reliability, Currency, Completeness, Timeliness. Based on the comparison of male and female university students. Service quality refers to "responsiveness," which is a very important indicator. It means how efficiently the technical department responds to the queries of users. Also, empathy is another characteristic of Service quality of how attentively they are helping the users (Petter et al. 2013; Haryaka et al. 2017; Xu and Du 2018).

Moreover, in the D\&M Model, service quality was neglected and updated in D\&M (2013). IS Success Model. Many items have been stated to measure E-learning system service quality but mostly cited instrument developed by authors (Parasuraman et al. 1986; Parasuraman et al. 1988; Parasuraman et al. 2002). Initially, ten dimensions were used to measure service quality, which later transformed into five named; tangibles, reliability, responsibility, assurance, and empathy. This updated model of D\&M Model found very useful for evaluating the success of different types of technologies related application. Most of the studies used this model of an information system, ERP system success, e-procurement application, e-government application on the user perspective, E-banking application use success, and also several other online application successes business (Hsu et al. 2015; Almarashdeh 2016; Aparicio et al. 2017; Ojo 2017; Cidral et al. 2018; Aparicio et al. 2019). E-learning involves the usage of modern technology to impart learning; thus, the present study needs to investigate how the end-user accepts much E-learning portal success. Therefore, the present study highlighted the comparison between male and female students on the E-learning portal. Thus, Fig. 2 has shown the research framework of the present study and hypothesis.

$\mathbf{H}_{1}$ E-service quality has a significant positive impact between males and females on the System USE.

$\mathbf{H}_{2}$ E-service quality has a significant positive impact between males and females on user satisfaction.

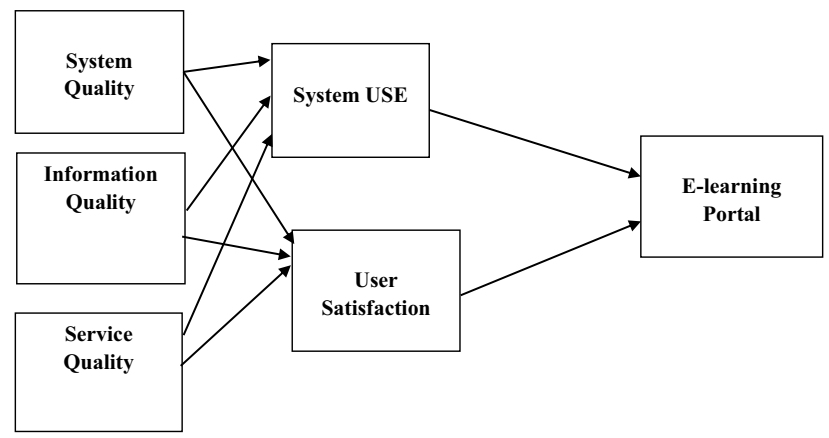

Fig. 2 The research Framework of the present study 
$\mathbf{H}_{3}$ Information quality has a significant positive impact between males and females on System USE.

$\mathbf{H}_{4}$ Information quality has a significant positive impact between males and females on user satisfaction.

$\mathbf{H}_{\mathbf{5}}$ System quality has a significant positive impact between males and females on System USE.

$\mathbf{H}_{\mathbf{6}}$ System quality has a significant positive impact between males and females on user satisfaction.

$\mathbf{H}_{7}$ System USE has a significant positive impact between males and females on the E-learning portal success.

$\mathbf{H}_{\mathbf{8}}$ : User satisfaction has a significant positive impact between males and females on the E-learning portal success.

\section{Methodology}

\subsection{Instrument development}

Based on previous research, the current study has developed a survey instrument. The questionnaire was adopted/adapted and reworded in the form of E-learning. All items used a 5point Likert scale ranging from 1 to 5 from "strongly disagree" to "strongly agree." The questionnaire items of system quality, information quality, system usage, satisfaction user was adopted from (McGill, Hobbs and Klobas, 2003; Rai, Lang and Welker, 2002). The E-learning portal success survey instrument items were adopted from (Freeze et al. 2010). All items of E-learning portal success were used a 5-point Likert scale ranging from 1-"Poor," 2-"Fair," 3-"Satisfactory," 4-"Very good" to 5-" Excellent."

\subsection{Data collection}

The research used a quantitative approach; the survey was conducted through the GOOGLE form; the links were shared with the student through the WhatsApp group of lecturers. All the Malaysian University student is participating in the E-learning portal survey. The convenience sampling technique was used. The study employed a cross-sectional survey method. In Table 1, the students of undergraduate 212 (75.7\%) and Postgraduate 68 (24.3\%) have participated in the online survey conducted from August to September 2019.

Table 1 Student Participated in the Survey based on the Program enrolled

\begin{tabular}{lcc}
\hline Program enrolled & Total & Percent \\
\hline Postgraduate & 68 & 24.2 \\
Undergraduate & 212 & 75.7 \\
Total & 280 & 100 \\
\hline
\end{tabular}


Table 2 Demographic Profile of Respondents $(\mathrm{N}=280)$

\begin{tabular}{lcc}
\hline Demographics respondents percentage (\%) & Frequency & Percentage \\
\hline Gender & & \\
Male & 90 & 32.1 \\
Female & 190 & 67.9 \\
Age-Group & 18 & \\
Less than 20 years & 212 & 75.7 \\
21-30 years & 36 & 12.9 \\
31-40 Years & 14 & 5.0 \\
More than 41 years & & \\
Experience Using the E-learning portal & 30 & 10.7 \\
Less than 1 year & 151 & 53.9 \\
More than 1 to 2 years & 99 & 35.0 \\
More the 3 &
\end{tabular}

\subsection{Data analysis}

In Table 2, In the demographic analysis, the 'gender' factor showed that female participants have a more response rate of $67.9 \%$ as compared to $32.1 \%$ who were male. In Malaysian Universities is more enrolment of female as compared to male. Regarding the 'age group' of respondents, data revealed that the majority was having the age-group of respondents 21-30 years 212 (75.7\%). Also, regarding the "Experience Using the E-learning portal," data showed that most of the students who participated in the survey they have experienced using the E-learning portal is more than two years.

\section{Data analysis in SmartPLS}

To achieve the research objectives, the study has employed Partial Least Squares (PLS) version 3.3.0 to facilitate data analysis. Based on the context of inferential analyses, Partial Least Squares-Structural Equation Modelling (PLS-SEM) application has been applied in several disciplines (Hair et al. 2016). These developments contribute to the growth of PLSSEM that is generally used as a research instrument in the field of management information systems as well as the social sciences (Hair et al. 2016). Also, confirm the importance of PLS's ability to analyze variables in complex models, simultaneously. Smart PLS evaluates two models, mainly, which are measurement and structural (Hair et al. 2016).

\subsection{Internal consistency reliability}

Internal consistency mentions the degree to which all indicators are different then each other (sub) scale is evaluating an equivalent concept (Hair et al. 2016). Inline thereupon, the composite reliability score value must be higher than 0.70 , and the AVE score value to quite 0.50 (Hair et al. 2013, 2016). Therefore, it explained in Table 3 below, all the constructs included in the present study have AVE, and composite reliability (CR) is above the criteria above said, which may be a suggestion of measurement model reliability. While Table 3 stated that the average variance extracted (AVE) and CR values of all variables are 
Table 3 Assessment Result for the measurement model

\begin{tabular}{|c|c|c|c|c|c|c|c|c|c|}
\hline \multicolumn{10}{|c|}{ Assessment Result for the measurement model } \\
\hline \multirow{2}{*}{$\begin{array}{l}\text { Construct/Asso- } \\
\text { ciated Items } \\
\text { Reflective }\end{array}$} & \multicolumn{3}{|l|}{ Loading } & \multicolumn{3}{|l|}{$\mathrm{CR}$} & \multicolumn{3}{|l|}{ AVE } \\
\hline & Full model & Female & Male & Full Model & Female & Male & Full Model & Female & Male \\
\hline $\begin{array}{l}\text { E-Learning Por- } \\
\quad \text { tal Success }\end{array}$ & & & & 0.968 & 0.969 & 0.963 & 0.883 & 0.888 & 0.868 \\
\hline ELP1 & 0.942 & 0.940 & 0.944 & & & & & & \\
\hline ELP2 & 0.941 & 0.943 & 0.935 & & & & & & \\
\hline ELP3 & 0.943 & 0.942 & 0.942 & & & & & & \\
\hline ELP4 & 0.932 & 0.943 & 0.906 & & & & & & \\
\hline E Service Quality & & & & 0.954 & 0.947 & 0.966 & 0.776 & 0.749 & 0.826 \\
\hline ESQ1 & 0.885 & 0.880 & 0.895 & & & & & & \\
\hline ESQ2 & 0.886 & 0.879 & 0.901 & & & & & & \\
\hline ESQ3 & 0.867 & 0.854 & 0.892 & & & & & & \\
\hline ESQ4 & 0.885 & 0.869 & 0.916 & & & & & & \\
\hline ESQ7 & 0.871 & 0.844 & 0.911 & & & & & & \\
\hline ESQ8 & 0.892 & 0.866 & 0.937 & & & & & & \\
\hline $\begin{array}{c}\text { Information } \\
\text { Quality }\end{array}$ & & & & 0.945 & 0.948 & 0.942 & 0.812 & 0.821 & 0.801 \\
\hline IQ1 & 0.891 & 0.892 & 0.894 & & & & & & \\
\hline IQ3 & 0.895 & 0.916 & 0.862 & & & & & & \\
\hline IQ4 & 0.916 & 0.913 & 0.919 & & & & & & \\
\hline IQ5 & 0.903 & 0.903 & 0.904 & & & & & & \\
\hline System Quality & & & & 0.949 & 0.949 & 0.951 & 0.789 & 0.787 & 0.796 \\
\hline SQ1 & 0.865 & 0.853 & 0.889 & & & & & & \\
\hline SQ2 & 0.918 & 0.919 & 0.914 & & & & & & \\
\hline SQ3 & 0.892 & 0.888 & 0.896 & & & & & & \\
\hline SQ4 & 0.887 & 0.890 & 0.888 & & & & & & \\
\hline SQ5 & 0.879 & 0.883 & 0.874 & & & & & & \\
\hline System USE & & & & 0.851 & 0.848 & 0.856 & 0.662 & 0.658 & 0.667 \\
\hline SU1 & 0.910 & 0.924 & 0.872 & & & & & & \\
\hline SU2 & 0.884 & 0.887 & 0.875 & & & & & & \\
\hline SU3 & 0.614 & 0.577 & 0.689 & & & & & & \\
\hline User Satisfaction & & & & 0.951 & 0.945 & 0.962 & 0.830 & 0.810 & 0.864 \\
\hline USAT1 & 0.905 & 0.877 & 0.945 & & & & & & \\
\hline USAT2 & 0.907 & 0.898 & 0.919 & & & & & & \\
\hline USAT3 & 0.896 & 0.892 & 0.905 & & & & & & \\
\hline USAT4 & 0.937 & 0.931 & 0.949 & & & & & & \\
\hline
\end{tabular}

in an appropriate range. It shows that all the constructs of the female and male groups have AVE's and CR value are above the threshold values, which proved the reliability of the measurement model (Figs. 3, 4, 5). 


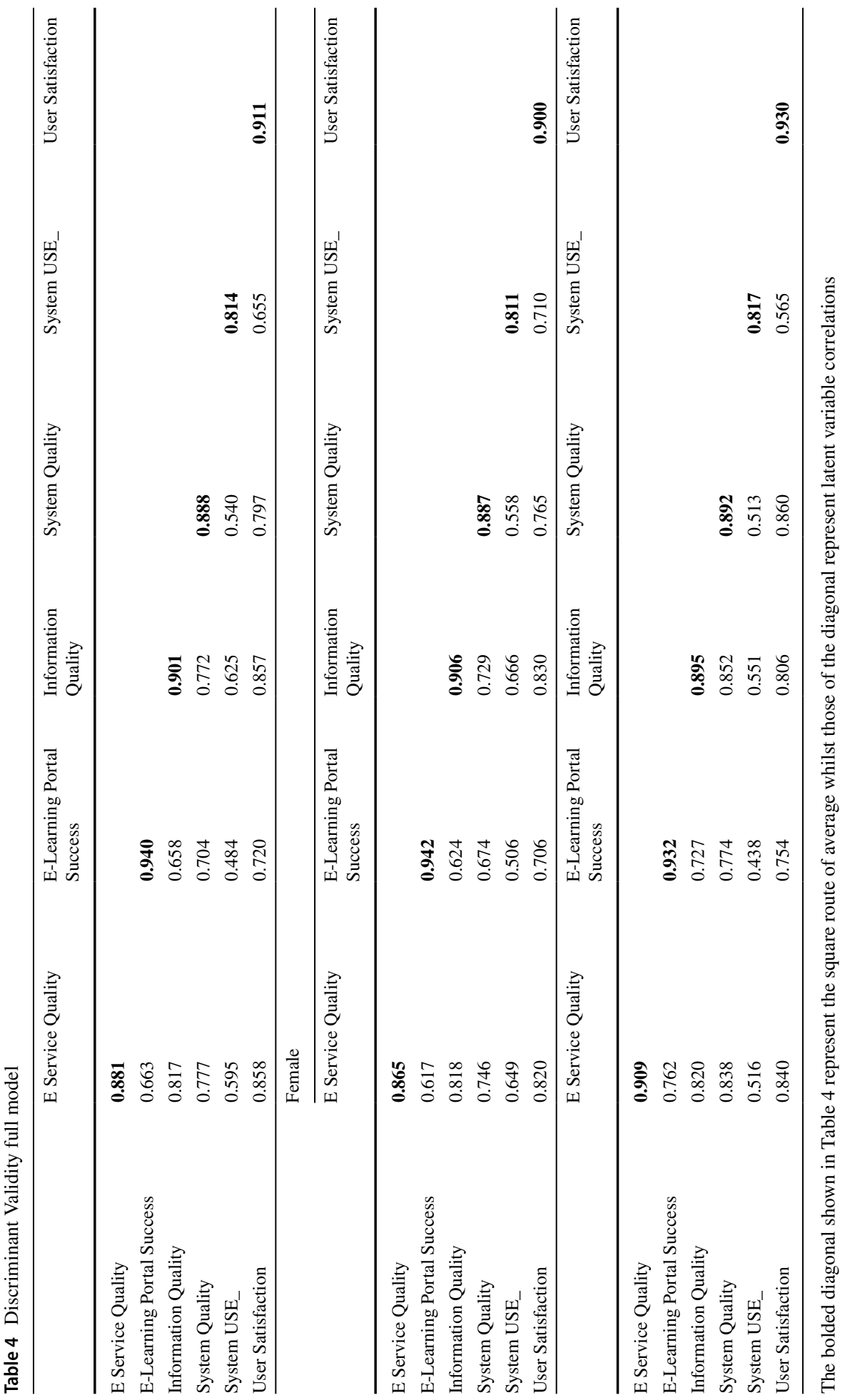




\subsection{Discriminant validity}

In the present study, also check the discriminant validity criterion, which measures the degree to which a variable is not equivalent to other constructs (Hair et al. 2016). According to Fornell \& Lacker criterion explained that the higher level of discriminant validity proposes that constructs are differents than the respective variables and not explaining some phenomena. The present study performed the discriminant validity taking the square root of AVE of the constructs. Thus, the values are higher than the correlations among latent constructs (Hwang and Min 2015). Therefore, in Table 4, the present study of male and female and full model having no issues with discriminant validity (Naala et al. 2017).

\subsection{Assessment of measurement invariance}

The measure two sets of university students, male and female, the study applies an invariance test. At the same, it is vital to conduct the invariance test before conducting a multi-group analysis. Thus, the purpose is to determine "whether, under different conditions of observing and studying phenomena, measurement models yield measures of the same attribute" (Henseler et al. 2016). Afterward, the study follows three steps, namely, Configural invariance, Compositional invariance, and Equality of composite means values and variances to test measurement invariance (Henseler et al. 2016).

Firstly, since the measurement models have the same number of constructs for both groups, therefore the Male and female group data is established for configural invariance (see Tables 3,4). secondly, compositional invariance was measured engaging a permutation test. This assures that the composite scores are the same between the groups.

Lastly, Equality of composite variances and means values of groups were assessed. Thus, the difference of the composite's mean and variance ratio results, as shown in Table 5, must fall within the $95 \%$ confidence interval. As indicated in Table 5, the result reveals that each of the composite constructs has non-significant differences regarding the composite mean and variances ratio. Moreover, in Table 5, full measurement invariance is depicted for Male and Female. Therefore, it is often deduced that the various model estimations of Male and female groups students are not distinct in terms of content or usage of the E-learning portal.

\subsection{Assessment of group differences}

In the current study, the researchers have applied PLS-MGA in order to calculate the differences by using Welch-Satterthwait Test on Male and female groups (Sarstedt et al. 2011). Furthermore, Table 6 is depicting the path coefficient and difference of the composite's means. Meanwhile, several paths are found to be different in terms of male and female data sets and significantly different. The present study found the E-service quality toward the system use male and female have a difference. On the otherwise information quality toward the system use having a difference between the male and female.

\subsubsection{Assessment of female group}

As per the female group assessment concerned in Table 6, hypothesis 1 predicted that ESQ is positively significantly related to System USE with Path Coefficient of $\left(0.285^{* *}\right)$, while 
( $p$ value $>0.05$ ) not supporting hypothesis 1 . Thus, hypothesis 2 , demonstrate the significant positive association among ESQ and US $(\beta=0.503, p$ value $<0.05)$ hypothesis 2 supported. Hypothesis 3 articulated that Information Quality is significant positively linked with System USE ( $\beta=0.388, p$ value $>0.05$ ), not supporting hypothesis 3 . Equally, hypothesis 4 , demonstrates a significant positive association with IQ and US $(\beta=0.287, p$ value $<0.05)$ supporting hypothesis 4.

Furthermore, Hypothesis 5 predicted that System Quality is insignificant negatively associated with System USE $(\beta=0.063, p$ value $>0.05$ ), not supporting hypothesis 5 . Results of hypothesis 6 demonstrate a significant positive association between System Quality and User Satisfaction $(\beta=0.181, p$ value $>0.05)$, not supporting hypothesis 6 . Hence, Hypothesis 7 articulated that system USE is significant positively linked with E-learning portal success $(\beta=0.008, p$ value $>0.05)$, not supporting hypothesis 7 . Finally, hypothesis 8 , demonstrates an insignificant negative association with User Satisfaction and E-learning portal success $(\beta=0.701, p$ value $>0.05)$, not supporting hypothesis 8 . Therefore, based on the above evidence, it can be concluded that female students more understand the important usage of E-learning portal success in the content of the university. This implies that female students hold the dominant positions on the usage of the E-learning portal.

\subsubsection{Assessment of male group}

Regarding male group assessment, Table 6 hypothesized that ESQ is negatively insignificantly related to System USE with $(\beta=0.165, p$ value $>0.05)$ not supporting hypothesis 1 . Next, with hypothesis 2, that demonstrates an insignificant negative association between ESQ and US $(\beta=0.204, p$ value $<0.05)$ hypothesis 2 supporting. While hypothesis 3 articulated that IQ is significant positively linked with System USE $(\beta=0.354, p$ value $>0.05)$, not supporting hypothesis 3 . Additionally, hypothesis 4 , demonstrates a significant positive association with Information Quality and User Satisfaction $(\beta=0.551, p$ value $<0.05)$ supporting hypothesis 4.

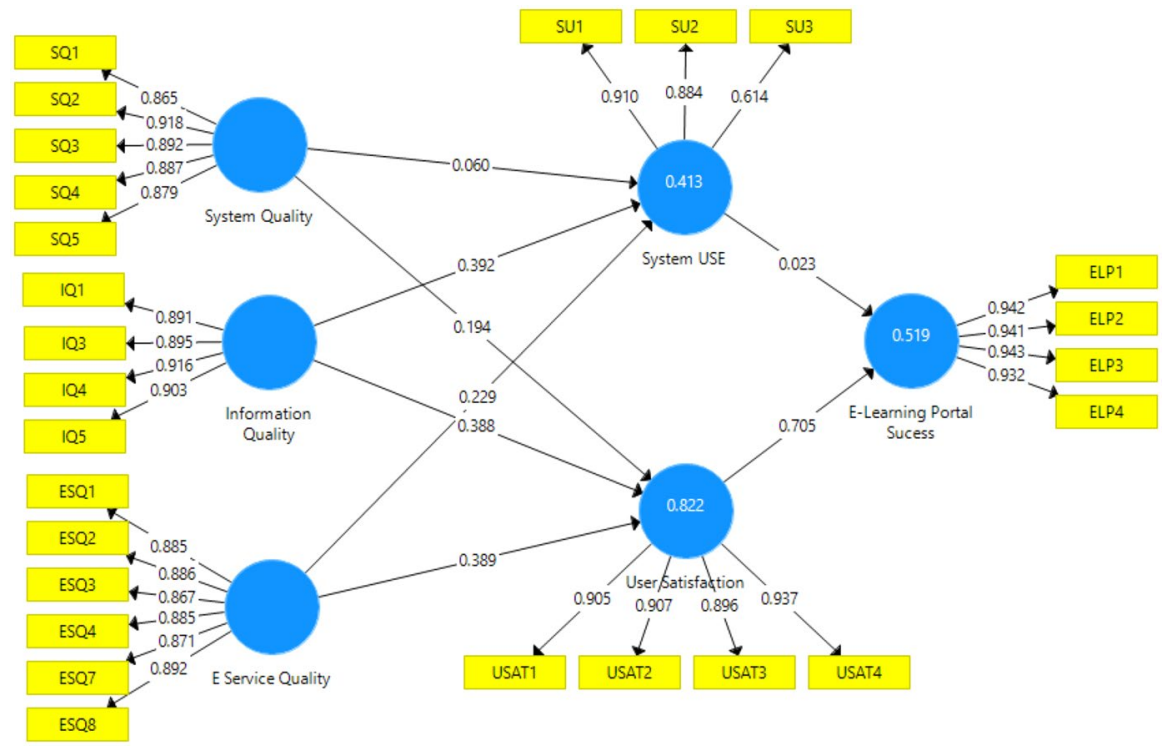

Fig. 3 Full Measurement Model 


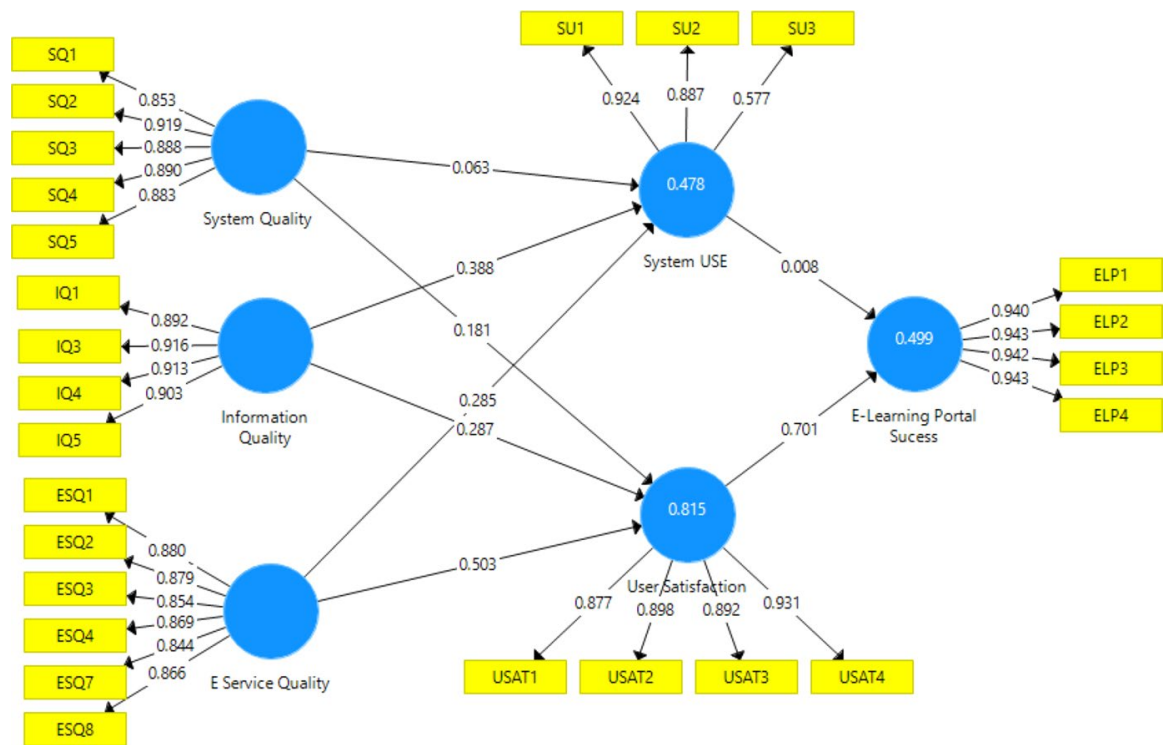

Fig. 4 Female measurement Model

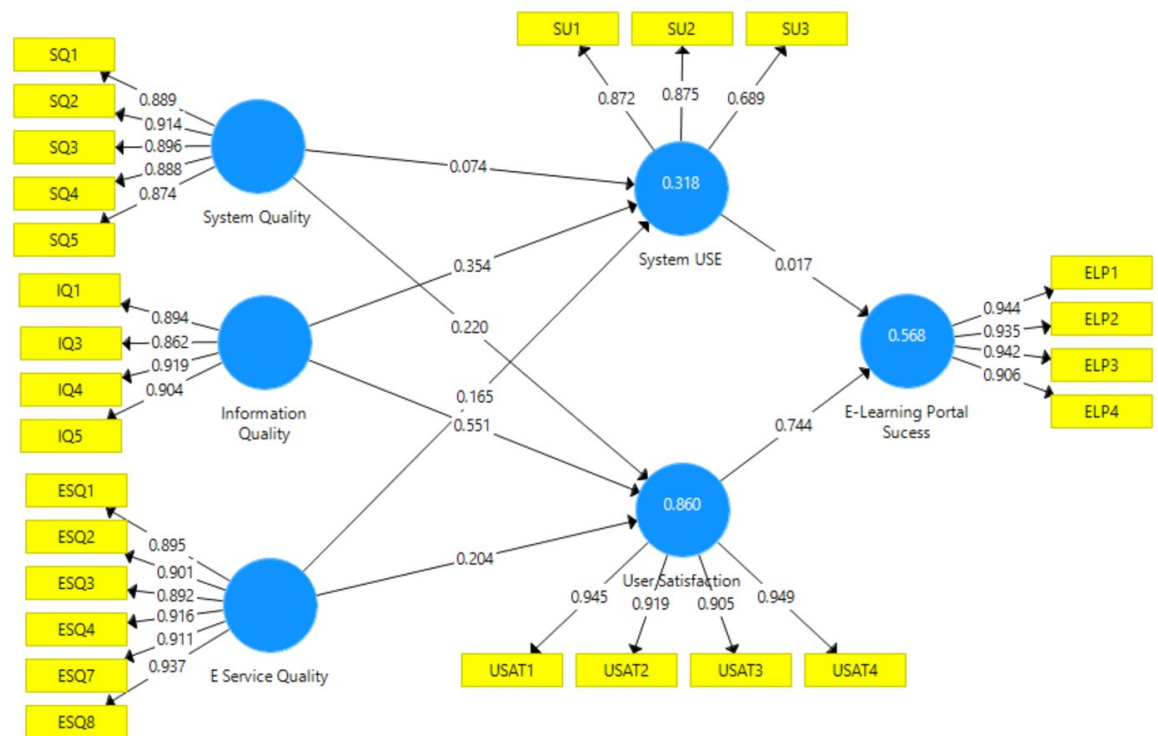

Fig. 5 Male measurement Model

Consequently, hypothesis 5 revealed that system quality is insignificant negatively associated with System USE ( $\beta=0.074, p$ value $>0.05$ ), not supporting hypothesis 5 . Results of hypothesis 6 demonstrate a significantly positive association between SQ and US ( $\beta=0.220$, $p$ value $>0.05$ ), not supporting hypothesis 6. Thus, Hypothesis 7 articulated that System USE is significant positively linked with E-learning Portal success $(\beta=0.017, p$ value $>0.05)$ not 


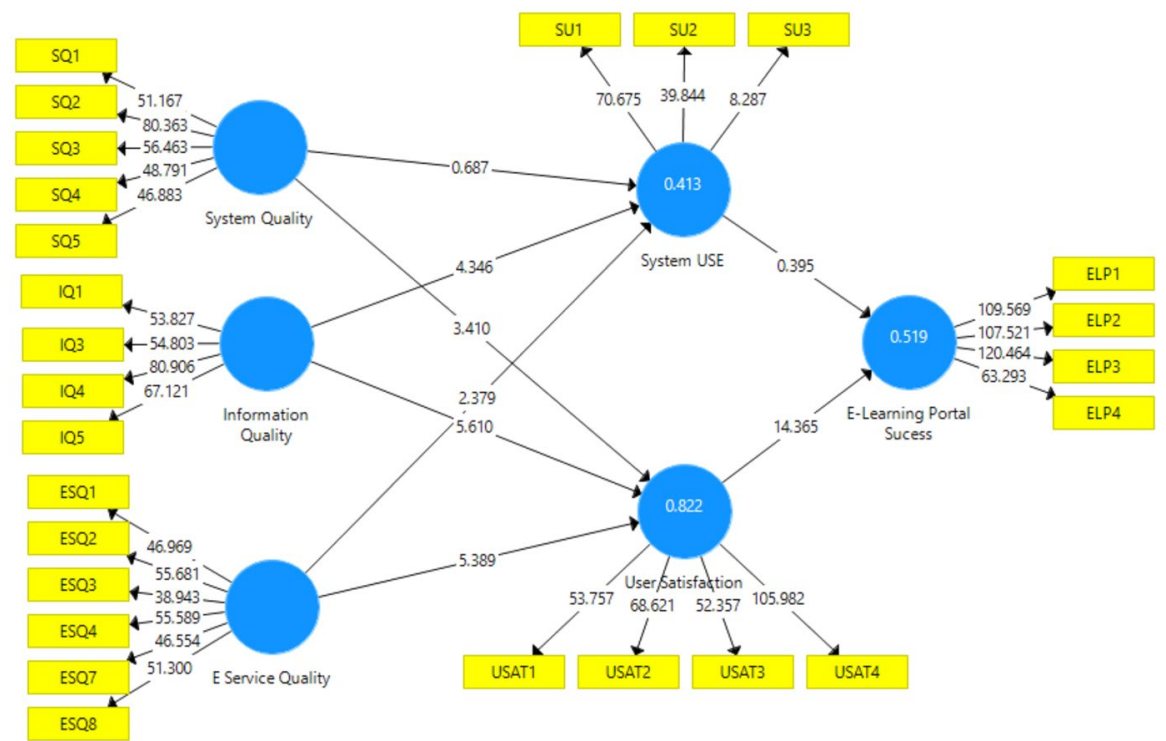

Fig. 6 Structure model

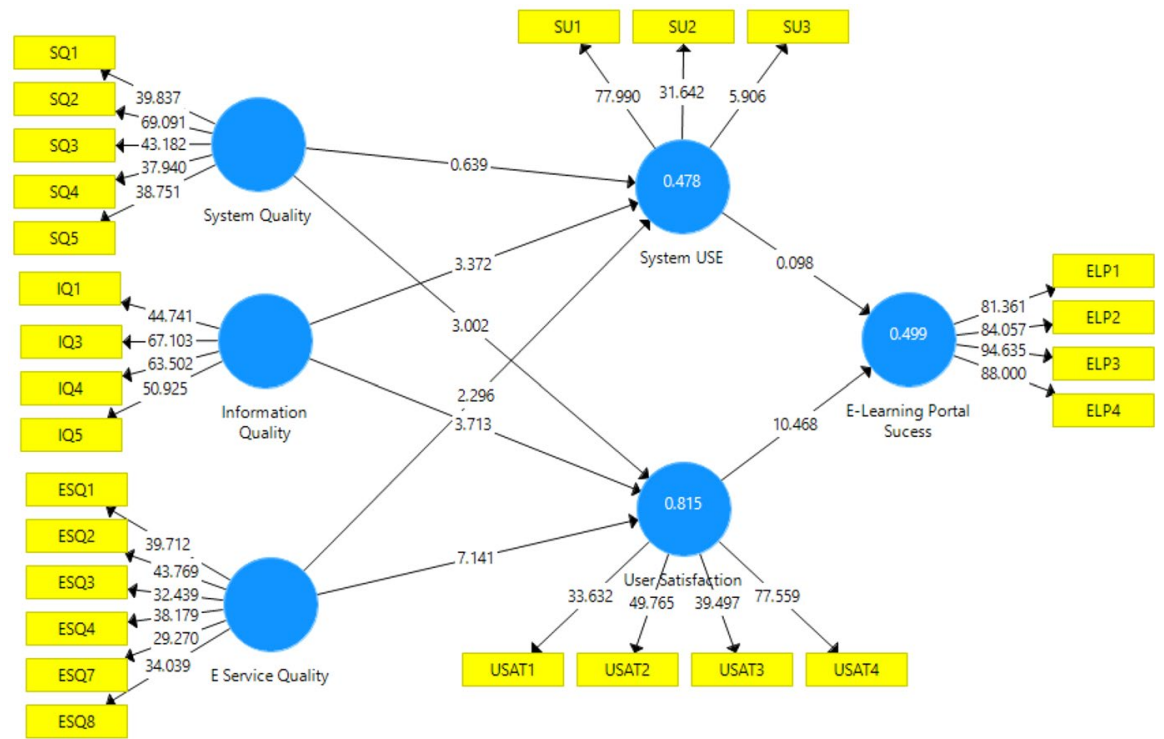

Fig. 7 Female Structure model

supporting hypothesis 7. Lastly, hypothesis 8, demonstrates an insignificant negative association with User Satisfaction and E-learning Portal success $(\beta=0.744, p$ value $>0.05)$ not supporting hypothesis 8. Meanwhile, this implies that male students are low concerned or understand the usage of E-learning portal success based on Path Coefficient results (Table 7) and (Figs. 6, 7, 8). 


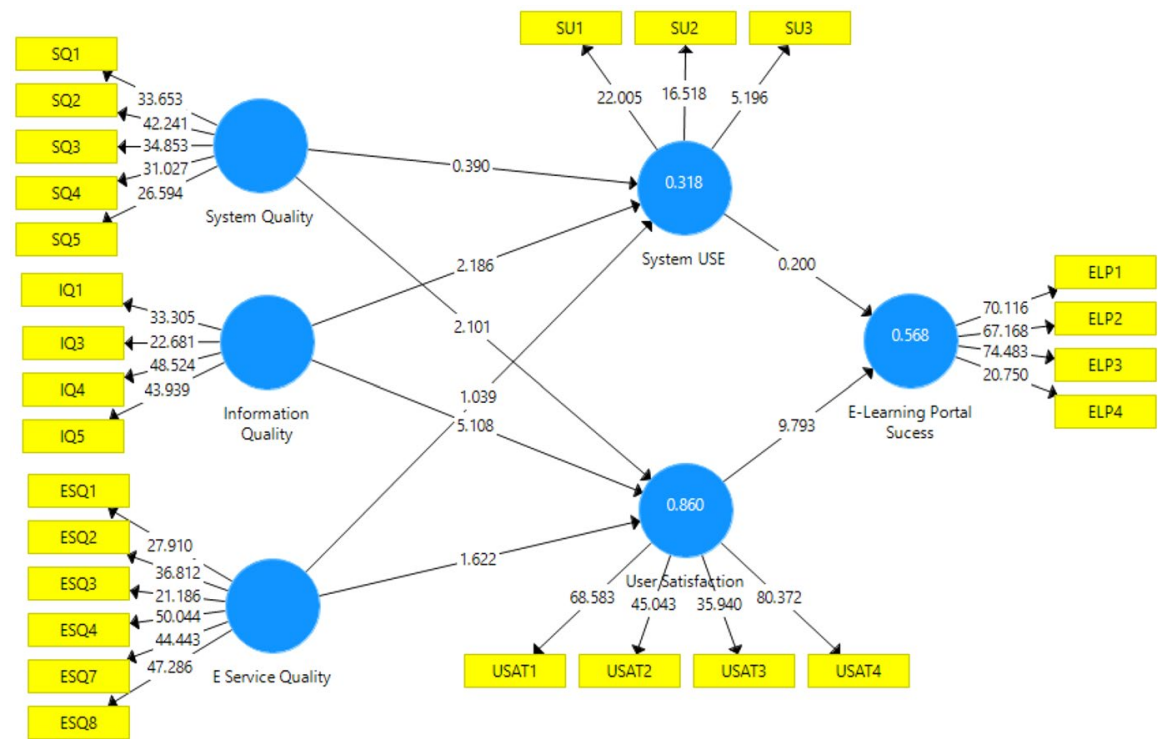

Fig. 8 Male Structure model

Table 5 Measurement invariance test using MICOM

\begin{tabular}{llll}
\hline Composite & C value $(=1)$ & $95 \%$ confidence & $\begin{array}{l}\text { Compositional } \\
\text { invariance }\end{array}$ \\
\hline E Service Quality & 1.000 & {$[1.000,1.000]$} & Yes \\
E-Learning Portal Sucess & 1.000 & {$[1.000,1.000]$} & Yes \\
Information Quality & 1.000 & {$[1.000,1.000]$} & Yes \\
System Quality & 1.000 & {$[0.999,1.000]$} & Yes \\
System USE_ & 0.992 & {$[0.996,1.000]$} & Yes \\
User Satisfaction & 1.000 & {$[1.000,1.000]$} & Yes \\
\hline Composite & Difference of the composite's & $95 \%$ confidence & Equal Mean \\
& mean value $(=0)$ & & Values \\
\hline E Service Quality & -0.060 & {$[-0.209,0.195]$} & Yes \\
E-Learning Portal Sucess & -0.270 & {$[-0.219,0.203]$} & No \\
Information Quality & -0.107 & {$[-0.214,0.201]$} & Yes \\
System Quality & -0.048 & {$[-0.216,0.195]$} & Yes \\
System USE_ & -0.136 & {$[-0.211,0.212]$} & Yes \\
User Satisfaction & -0.115 & {$[-0.210,0.209]$} & Yes \\
\hline Composite & Difference of the composite's & $95 \%$ confidence & Equal variances \\
& mean value $(=0)$ & & \\
\hline E Service Quality & -0.336 & {$[-0.338,0.368]$} & Yes \\
E-Learning Portal Sucess & 0.011 & {$[-0.213,0.252]$} & Yes \\
Information Quality & -0.166 & {$[-0.305,0.342]$} & Yes \\
System Quality & -0.068 & {$[-0.293,0.344]$} & Yes \\
System USE_ & 0.054 & {$[-0.325,0.356]$} & Yes \\
User Satisfaction & -0.320 & & Yes \\
\hline & & &
\end{tabular}




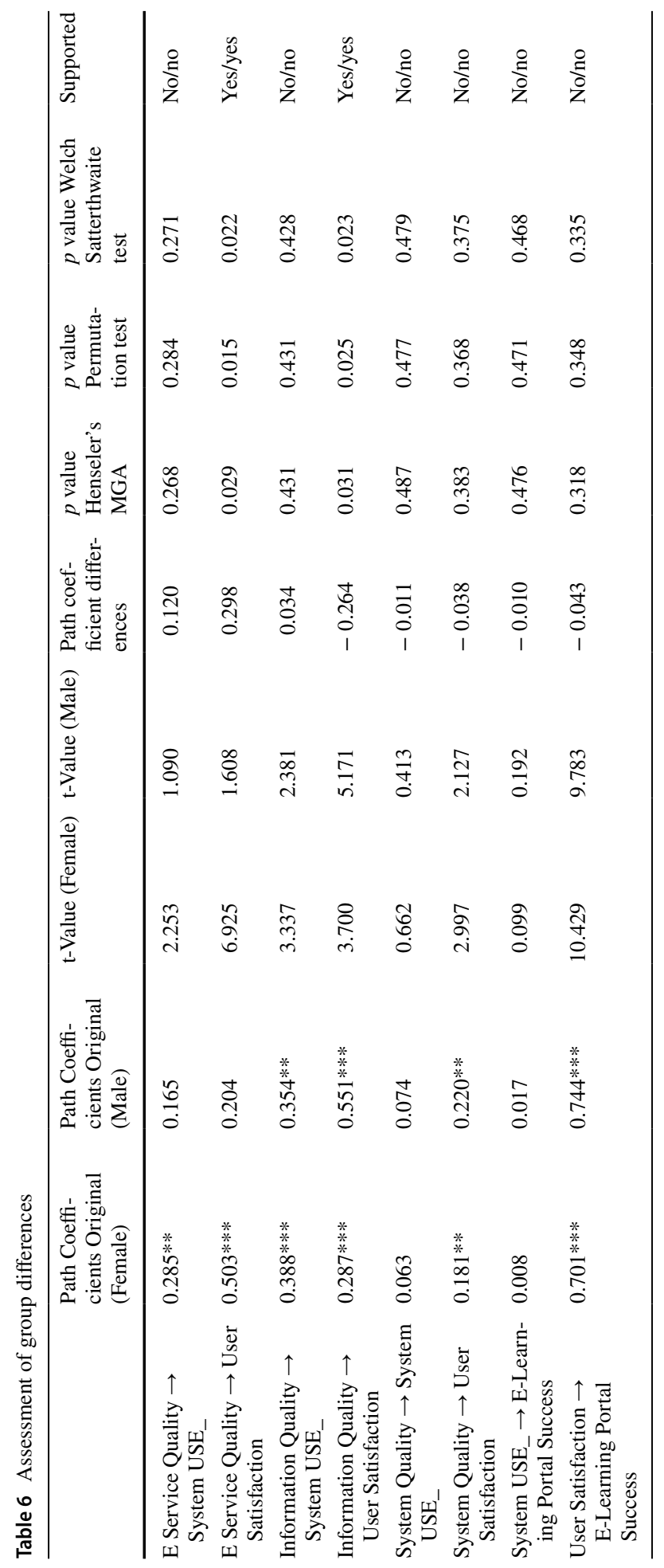




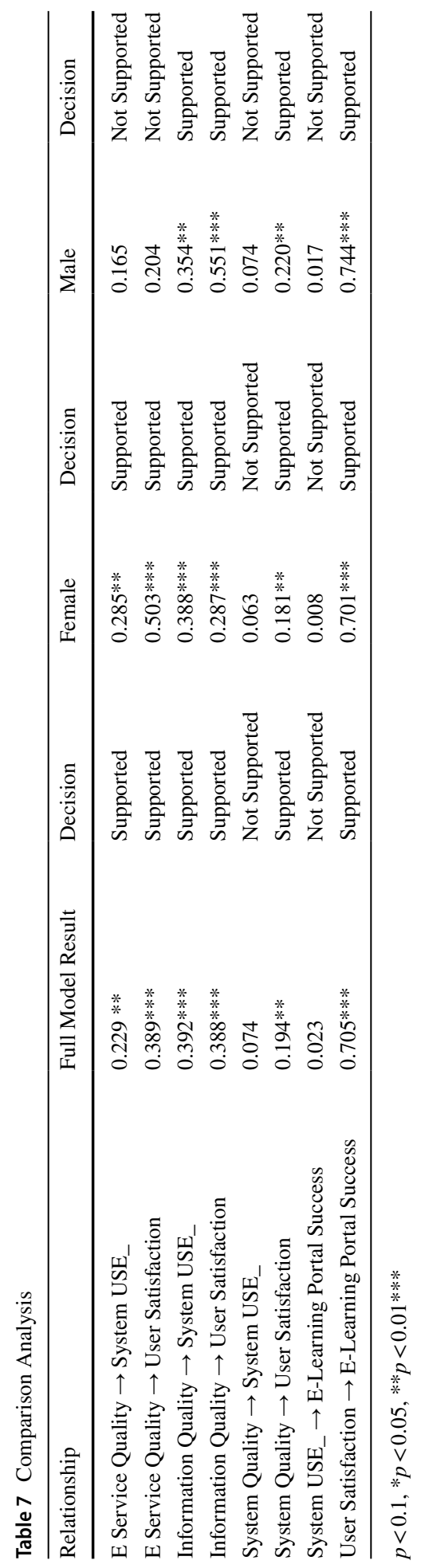




\section{Results comparison}

In regard to the hypothesis testing on the female group, six (6) variables were, directly and indirectly, significant and supported to E-learning Portal Success. In the female students model, E-service quality and Information quality both are supported with system use and user satisfaction. Similarly, system quality has a positive relationship with user satisfaction, and user satisfaction has a positive relationship with E-learning portals. On the other hand, in male students, four (4) variables are significant. More precisely, information quality and system quality have direct relationships with user satisfaction. Information quality also supported the relationship with system use. At the same time, there is a positive relationship between user satisfaction and E-learning portals. In the full model, user satisfaction is significant in terms of information quality and service quality. Consequently, user satisfaction is also significant in terms of E-learning portals. Thus, E-learning portal usage is more towards female students in Malaysian Universities.

\subsection{Theoretical implication}

Regarding theoretical implication, the adoption studies are numerously studied phenomena both at an individual (customer) as well as organizational (management) levels. Although, technology adoption studies like E-learning portals success among students is a rarely researched phenomenon, particularly in Malaysian universities. The present study is considered a pioneer in terms of E-portals implementation in universities to test empirical, theoretical relationships in terms of males and females. Mainly, it elaborated on the relationship between the variables such as E-learning Portal Success, ESQ, IQ, SQ, SU has a significant impact on US. This present study proposes and examined the factors that affect the E-learning portal by extending D \& M theory to incorporate elements that are more associated with the IS Success and E-learning among university students. Additionally, D \& M model is taken into account because the IS tangible factors that would help universities strengthen and enhance their services. The significant contribution of the present study is the behavior of model changes if we divide the full model into parts (Male and Females). The proposed that D and M models provide misleading out in terms of the full model. Thus, its theoretical relationship changes as the model divided into different subgroups. This confirms the effectiveness of the E-learning portals in different for male and female students of Malaysian Universities.

\subsection{Practical implications}

The current study, in the context of Malaysian as well as other countries' universities, has numerous implications related to E-learning Portals technology. The study will be further helpful for the Malaysian Government and university policy-makers such as top management, ministry of higher education, Malaysian universities union in designing the policies and programs on E-learning Portal Success in the country. At the same time, university top management/dean of faculty and HOD of the department need to concentrate on the importance of enhancing university quality education. The study further implies that females students of Malaysian universities are more focused on the E-learning portal as compare to male students. In the COVID-19 outbreak, the operational habits have changed around the globe within a short period, and mainly the education sector affected worldwide. In the 
future, most of the universities will be offering online courses to the students. The COVID19 will create a long-term impact on higher education institutions. If the pandemic remains longer, it might change education from face to face to online. Based on that, the quality of the E-learning system, quality of information that will create an impact on user satisfaction and system use that will lead toward the E-learning portals. It will decrease the education cost, and education will reach outside the border as well. Education will be borderless in 5 to 10 years. This study recommends some of the suggestion to higher education institution such accessibility of the E-learning portal 24/7, error-free information, quality of information, content quality, the robustness of the server, training module materials related to E-learning portal use for new users, updated information, well-organized data, userfriendly design of the portal, and time to time feedback from the user will increase the durability and acceptability of the E-learning portal.

\section{Conclusion}

This study focuses on comparisons between male and female counterparts on E-learning portal usage among university students. E-learning portal services adaptability in the among the student perspective of male and female. The present study highlight difference between the male and female success-fully use on the E-learning portal in Malaysia. While future studies will have to consider some variables like (Technology infrastructure support, system change perceived of use, perceived usefulness, user's perception, and technical expertise), moreover, the further studies can be conducted by applying longitudinal design to empirically test the theoretical constructs by analyzing other countries' universities. In the end, top management of universities is provided with recommendations for developing an understanding of the implication of E-service quality, information quality, system quality, system USE, and user satisfaction concerning the E-learning portal success.

Acknowledgements The authors would like to thank the anonymous referees for providing helpful comments and suggestions which lead to the improvement of the paper.

Funding This research received no external funding.

\section{Compliance with ethical standards}

Conflicts of interest The authors declare no conflicts of interest.

\section{References}

Adams, D., Sumintono, B., Mohamed, A., Noor, N.S.M.: E-learning readiness among students of diverse backgrounds in a leading malaysian higher education institution. Malaysian Journal of Learning and Instruction 15(2), 227-256 (2018)

Almarashdeh, I.: Sharing instructors' experience of learning management system: A technology perspective of user satisfaction in distance learning course. Computers in Human Behavior 63, 249-255 (2016). https://doi.org/10.1016/j.chb.2016.05.013

Aljawarneh, S.A.: Reviewing and exploring innovative ubiquitous learning tools in higher education. Journal of computing in higher education 32(1), 57-73 (2020). https://doi.org/10.1007/s12528-019-09207 $-0$ 
Alvino, F., Di Vaio, A., Hassan, R., Palladino, R.: Intellectual capital and sustainable development: A systematic literature review. Journal of Intellectual Capital (2020). https://doi.org/10.1108/ JIC-11-2019-0259

Aparicio, M., Bacao, F., Oliveira, T.: Grit in the path to E-learning success. Computers in Human Behavior 66, 388-399 (2017). https://doi.org/10.1016/j.chb.2016.10.009

Aparicio, M., Oliveira, T., Bacao, F., Painho, M.: Gamification: A key determinant of massive open online course (MOOC) success. Information Management 56(1), 39-54 (2019). https://doi.org/10.1016/j. im.2018.06.003

Azhari, F.A., Ming, L.C.: Review of E-learning practice at the tertiary education level in Malaysia. Indian Journal of Pharmaceutical Education and Research 49(4), 248-257 (2015). https://doi.org/10.5530/ ijper.49.4.2

Azzi-Huck, K. and T. Shmis. Managing the impact of COVID-19 on education systems around the world: How countries are preparing, coping, and planning for recovery. (2020)

Beheshti, H.M., Beheshti, C.M.: Improving productivity and firm performance with enterprise resource planning. Enterprise Information Systems 4(4), 445-472 (2010). https://doi.org/10.1080/17517 575.2010.511276

Cai, L., Zhu, Y.: The challenges of data quality and data quality assessment in the big data era. Data Science Journal (2015). https://doi.org/10.5334/DSJ-2015-002

Calisir, F., Altin Gumussoy, C., Bayraktaroglu, A.E., Karaali, D.: Predicting the intention to use a webbased learning system: Perceived content quality, anxiety, perceived system quality, image, and the technology acceptance model. Human Factors and Ergonomics in Manufacturing \& Service Industries 24(5), 515-531 (2014). https://doi.org/10.1002/hfm.20548

Chen, H.J.: Linking employees'E-learning system use to their overall job outcomes: An empirical study based on the IS success model. Comput. Educ. 55(4), 1628-1639 (2010). https://doi.org/10.1016/j. compedu.2010.07.005

Chiang, C.-Y., Boakye, K., Tang, X.: The investigation of E-learning system design quality on usage intention. Journal of Computer Information Systems 59(3), 256-265 (2019). https://doi.org/10.1080/08874 417.2017.1342176

Chopra, G., Madan, P., Jaisingh, P., Bhaskar, P.: Effectiveness of E-learning portal from students' perspective: A structural equation model (SEM) approach. Interactive Technology and Smart Education 16(2), 94-116 (2019). https://doi.org/10.1108/ITSE-05-2018-0027

Cidral, W.A., Oliveira, T., Di Felice, M., Aparicio, M.: E-learning success determinants: Brazilian empirical study. Computer Education 122, 273-290 (2018). https://doi.org/10.1016/j.compedu.2017.12.001

Davis, F.D.: Perceived usefulness, perceived ease of use, and user acceptance of information technology. MIS Quarterly (1989). https://doi.org/10.2307/249008

DeLone, W.H., McLean, E.R.: Information systems success: The quest for the dependent variable. Information Systems Research 3(1), 60-95 (1992)

Delone, W.H., McLean, E.R.: The DeLone and McLean model of information systems success: A ten-year update. Journal of Management Information Systems 19(4), 9-30 (2003). https://doi. org/10.1080/07421222.2003.11045748

DeLone, W.H., McLean, E.R.: Information systems success measurement. Foundations and Trends® in Information Systems 2(1), 1-116 (2016). https://doi.org/10.1561/2900000005

Di Vaio, A., Boccia, F., Landriani, L., Palladino, R.: Artificial intelligence in the agri-food system: Rethinking sustainable business models in the COVID-19 scenario. Sustainability 12(12), 4851 (2020a). https ://doi.org/10.3390/su12124851

Di Vaio, A., Palladino, R., Hassan, R., Alvino, F.: Human resources disclosure in the EU Directive 2014/95/ EU perspective: A systematic literature review. The Journal of Cleaner Production 257, 120509 (2020b)

Freeze, R.D., Alshare, K.A., Lane, P.L., Wen, H.J.: IS success model in E-learning context based on students' perceptions. Journal of Information systems education 21(2), 173 (2010)

Gable, G., Sedera, D., \& Chan, T. (2003). Enterprise systems success: a measurement model. ICIS 2003 Proceedings, 48. http://eprints.qut.edu.au/archive/00004743

Gros, B., García-Peñalvo, F.J.: Future trends in the design strategies and technological affordances of E-learning. Learning, Design, and Technology: An International Compendium of Theory, Research, Practice, and Policy (2016). https://doi.org/10.1007/978-3-319-17727-4_67-1

Gupta, S.B., Gupta, M.: Technology and E-learning in higher education. Technology 29(4), 1320-1325 (2020)

Hair Jr., J., Sarstedt, M., Hopkins, L., Kuppelwieser, G.V.: Partial least squares structural equation modeling (PLS-SEM) An emerging tool in business research. European Business Review 26(2), 106-121 (2016). https://doi.org/10.1108/EBR-10-2013-0128 
Hair, J.F., Ringle, C.M., Sarstedt, M.: Partial least squares structural equation modeling: Rigorous applications, better results and higher acceptance. Long Range Plan. 46(1-2), 1-12 (2013)

Haryaka, U., Agus, F., Kridalaksana, A.H.: User satisfaction model for E-learning using smartphone. Procedia Computer Science 116, 373-380 (2017). https://doi.org/10.1016/J.PROCS.2017.10.070

Henseler, J., Hubona, G., Ray, P.A.: Using PLS path modeling in new technology research: updated guidelines. Industrial Management \& Data Systems 116(1), 2-20 (2016). https://doi.org/10.1108/ IMDS-09-2015-0382

Hong, J.-C., Tai, K.-H., Hwang, M.-Y., Kuo, Y.-C., Chen, J.-S.: Internet cognitive failure relevant to users' satisfaction with content and interface design to reflect continuance intention to use a government E-learning system. Computers in Human Behavior 66, 353-362 (2017). https://doi.org/10.1016/j. chb.2016.08.044

Hsu, P.F., Yen, H.R., Chung, J.C.: Assessing ERP post-implementation success at the individual level: Revisiting the role of service quality. Information \& Management 52(8), 925-942 (2015). https:// doi.org/10.1016/j.im.2015.06.009

Hussin, H., Bunyarit, F., Hussein, R.: Instructional design and E-learning: Examining learners' perspective in Malaysian institutions of higher learning. Campus-Wide Information Systems 26(1), 4-19 (2009)

Hwang, D., Min, H.: Identifying the drivers of enterprise resource planning and assessing its impacts on supply chain performances. Industrial Management \& Data Systems 115(3), 541-569 (2015). https ://doi.org/10.1108/IMDS-10-2014-0284

Ifinedo, P.: Extending the Gable et al enterprise systems success measurement model: A preliminary study. Journal of Information Technology Management 17(1), 14-33 (2006)

Ifinedo, P.: An empirical analysis of factors influencing Internet/e-business technologies adoption by SMEs in Canada. International Journal of Information Technology \& Decision Making 10(04), 731-766 (2011). https://doi.org/10.1142/S0219622011004543

Ifinedo, P.: Information systems security policy compliance: An empirical study of the effects of socialisation, influence, and cognition. Inf. Manag. 51(1), 69-79 (2014). https://doi.org/10.1016/j. im.2013.10.001

Margaryan, A., Bianco, M., Littlejohn, A.: Instructional quality of massive open online courses (MOOCs). Computter Education 80, 77-83 (2015). https://doi.org/10.1016/j.compedu.2014.08.005

Mason, R.O.: Measuring information output: A communication systems approach. Inf. Manag. 1(4), 219-234 (1978)

McGill, T., Hobbs, V., Klobas, J.: User-developed applications and information systems success: A test of DeLone and McLean's model. Information Resources Management Journal 16(1), 24-45 (2003)

Mohammadi, H.: Investigating users' perspectives on E-learning: An integration of TAM and IS success model. Computers in Human Behavior 45, 359-374 (2015). https://doi.org/10.1016/j. chb.2014.07.044

Moore, J.L., Dickson-Deane, C., Galyen, K.: E-learning, online learning, and distance learning environments: Are they the same? The Internet and Higher Education 14(2), 129-135 (2011). https://doi. org/10.1016/j.iheduc.2010.10.001

Muda, I., Erlina, A.A.: Influence of human resources to the effect of system quality and information quality on the user satisfaction of accrual-based accounting system. Contaduría y administración 64(2), 10 (2019). https://doi.org/10.22201/fca.24488410e.2019.1667

Naala, M.I.N., Nordin, N., Omar, W.A.W.: Innovation capability and firm performance relationship: A study of Pls-structural equation modeling (Pls-Sem). International Journal of Organization \& Business Excellence 2(1), 39-50 (2017). https://doi.org/10.1177/2158244020920892

Ojo, A.I.: Validation of the DeLone and McLean information systems success model. Healthcare Informatics Research 23(1), 60-66 (2017). https://doi.org/10.4258/hir.2017.23.1.60

Paechter, M., Maier, B.: Online or face-to-face? Students' experiences and preferences in E-learning. The internet and higher education 13(4), 292-297 (2010). https://doi.org/10.1016/j.iheduc.2010.09.004

Parasuraman, A., Berry, L., Zeithaml, V.: Refinement and reassessment of the SERVQUAL scale. Journal of Retailing 67(4), 114 (2002)

Parasuraman, A., Zeithaml, V.A., Berry, L.L.: Servqual: A multiple-item scale for measuring consumer perceptions of Service Quality. Marketing Science Institute, Campbridge, MA (1986)

Parasuraman, A., Zeithaml, V.A., Berry, L.L.: Servqual: A multiple-item scale for measuring consumer perc. Journal of Retailing 64(1), 12 (1988)

Petter, S., DeLone, W., McLean, E.R.: Information systems success: The quest for the independent variables. Journal of Management Information Systems 29(4), 7-62 (2013). https://doi.org/10.2753/ MIS0742-1222290401 
Pham, L., Limbu, Y.B., Bui, T.K., Nguyen, H.T., Pham, H.T.: Does E-learning service quality influence E-learning student satisfaction and loyalty Evidence from Vietnam. International Journal of Educational Technology in Higher Education (2019). https://doi.org/10.1186/s14239-019-0136-3

Rai, A., Lang, S., Welker, R.: Assessing the validity of IS success models: An empirical test and theoretical analysis. Information Systems Research 13(1), 50-69 (2002)

Sahu, P.: Closure of universities due to Coronavirus Disease 2019 (COVID-19): impact on education and mental health of students and academic staff. Cureus (2020). https://doi.org/10.7759/cureus.7541

Sarstedt, H., Ringle.: Multigroup analysis in partial least squares (PLS) path modeling: Alternative methods and empirical results. Measur. Res Methods. Int Mark 22, 195-218 (2011). https://doi. org/10.1108/S1474-7979(2011)0000022012

Selvaraj, C.: Success of e-learning systems in management education in chennai city-using user's satisfaction approach. The Online Journal of Distance Education and E-learning 7(2), 124 (2019)

Shahzad, A., Chin, H.K., Altaf, M., Bajwa, F.A.: Malaysian SMEs performance and the use of e-commerce: A multi-group analysis of click-and-mortar and pureplay E-retailers. Pakistan Journal of Commerce and Social Sciences (PJCSS) 14(1), 1-33 (2020a)

Shahzad, A., Hassan, R., Abdullah, N.I., Hussain, A., Fareed, M.: COVID-19 impact on e-commerce usage: An empirical evidence from Malaysian healthcare industry. Humanities \& Social Sciences Reviews 8(3), 599-609 (2020b). https://doi.org/10.18510/hssr.2020.8364.

Shannon, C.E., Weaver, W.: The mathematical theory of communication. University of Illinois Press, Urbana (1949)

Shereen, M.A., Khan, S., Kazmi, A., Bashir, N., Siddique, R.: COVID-19 infection: Origin, transmission, and characteristics of human coronaviruses. J Adv Res 24(7), 91-98 (2020). https://doi.org/10.1016/j. jare.2020.03.005

Xu, F., Du, J.T.: Factors influencing users' satisfaction and loyalty to digital libraries in Chinese universities. Computers in Human Behavior 83, 64-72 (2018). https://doi.org/10.1016/j.chb.2018.01.029

Yengin, I., Karahoca, A., Karahoca, D.: E-learning success model for instructors' satisfactions in perspective of interaction and usability outcomes. Procedia Computer Science 3, 1396-1403 (2011). https:// doi.org/10.1016/j.procs.2011.01.021

Sedera, Darshana, Rebekah Eden, and Ephraim McLean. "Are we there yet? A step closer to theorizing information systems success." (2013).

Publisher's Note Springer Nature remains neutral with regard to jurisdictional claims in published maps and institutional affiliations.

\section{Affiliations}

\section{Arfan Shahzad ${ }^{1} \cdot$ Rohail Hassan $^{1}\left(10\right.$ - Adejare Yusuff Aremu ${ }^{1}$ - Arsalan Hussain ${ }^{1}$. Rab Nawaz Lodhi ${ }^{2}$}

Arfan Shahzad

arfan@uum.edu.my

Adejare Yusuff Aremu

akogunadejare@yahoo.com

Arsalan Hussain

arsalanhussaink9@gmail.com

Rab Nawaz Lodhi

rabnawaz.lodhi@ucp.edu.pk

1 Othman Yeop Abdullah Graduate School of Business (OYAGSB), Universiti Utara Malaysia (UUM), 06010 Sintok, Kedah Darul Aman, Malaysia

2 UCP Business School, University of Central Punjab, Lahore, Pakistan 